that the Swedish Government had approved a grant of 100,000 Swedish crowns (about $f 8,000$ ) towards the provision of suitable premises for the collections. Linnaeus was of course a Swede, and the impetus for the gift seems to have come from the Royal Swedish Academy of Sciences at the instigation of Professor S. O. Horstadius, a foreign member of the Linnean Society. Other gifts from Sweden have come from HM the King, the University of Uppsala and the Swedish Match Co., as well as the Academy of Sciences.

The most generous single British donations have come from the Royal Society $(£ 4,970)$ and from the Drapers Company $(£ 5,000)$ towards the cost of a new council room as a memorial to the late Sir Frederick Stern, former master of the company and treasurer of the society. In its report on the appeal the society notes that the response of industry and commerce has been reasonable in view of the present financial climate and the rather specialized nature of the appeal. BP and ICI were the most generous donors, giving $£ 1,000$ and $£ 500$ respectively. Many scientific societies have also contributed, and the Linnean Society hopes that some of them will be able to make use of the modernized rooms for their meetings.

The work already completed or under way in the basement, which as well as the strongroom includes the provision of new cloakrooms and heating and ventilation systems, will cost about $£ 42,000$. Further plans have been drawn up for improvements to the library and lecture room and the provision of a council room and offices. This work, due to begin soon, will cost more than $£ 30,000$, and so the appeal is by no means closed. If sufficient funds are available there are a few more improvements, particularly to the library, which the society would like to see effected.

The library of the Linnean Society has considerable historical interest, because it is founded on the libraries of Linnacus himself and J. E. Smith, the wealthy friend of Sir Joseph Banks, who bought the collections and books for $£ 1,088$ ss from Linnaeus's family in 1783. The Linnean Society was formed five years later, meeting at the Marlborough Coffee House in London, with Smith as one of the seven founder members. After Smith's death in 1828 the society bought the collections and books from his executors, and has had them ever since.

\section{CARNEGIE OBSERVATORIES}

\section{Rechristening Mount Wilson}

THE Mount Wilson and Palomar Observatories in California are in future to be known jointly as the Hale Observatories. This was announced recently by the Carnegie Institution of Washington and the California Institute of Technology. The immediate benefit of the change will be that innocents will not in future fall into the trap of calling Palomar Mountain Mount Palomar, but it is also intended that there should be a new method of planning work at the observatories, which will separately be known by their old and separate names. The director of the observatories will remain Dr Horace W. Babcock, but the new arrangements specify that there should always be a director from one of the observatories and an associate director from the other. In fact, Dr J. Beverly Oke has been appointed associate director of the Hale Observatories. The allotment of observing time will be entrusted to an observatory committce of eight people.

The permanent staff of the observatories is now more than 120 strong and includes nineteen astronomers, many of whom are also members of the faculty at the California Institute of Technology. The naming of the observatories after George Ellery Hale is of course appropriate-Hale founded not merely the Mount Wilson and Palomar Observatories but also those at Kenwood and Yerkes. Although experienced people say that seeing conditions at Mount Wilson have never been as good as in the years during the war when Los Angeles was blacked out, the two observatories remain remarkably usable. The 200 -inch Hale telescope on Palomar Mountain, for example, had 238 complete nights of seeing in 1968 and 62 nights when it could be used for part of the time.

\section{Preventing a Flood}

\section{by our Planning Correspondent}

WhILE the British Government has not yet firmly committed itself to the form or the location of a barrage or barrier across the River Thames as a defence against a tidal flood, it has agreed that London and Lower Thames-side must be protected in some form, although it does not regard the likelihood of a serious flood with quite the same alarm as does the Greater London Council. Nevertheless, the Minister of Housing and Local Government, Mr Greenwood, did say in a written parliamentary answer on January 20 that no time should be lost in completing the further studies called for in a report on various defence systems which the GLC has just submitted to the minister, and that the government and the responsible authorities "will then decide as a matter of urgency on the nature and siting of the defences required".

The GLC report to which the minister referred contains the council's preliminary conclusions from a detailed study into what it believes to be the growing threat of a flood caused by a combination of circumstances-the sinking of the south-east at the rate of about a foot a century; the increasing height of the tides in the Thames (about 3 feet a century at London Bridge) compared with the general sea level; the reclamation of low lying land alongside the river over the centuries which has stopped the build-up of silt; and the channelling of the river through the building of flood walls which has raised the general level of water. A high spring tide, a "surge" of moving water from the North Atlantic, an adverse wind, heavy rainfall and drainage off the land could, in the council's opinion, cause a disastrous flood.

The council has worked on the basis of providing protection against a high water level six feet above the levels reached by the Thames in the floods of 1953 , taking into account the sinking of the land, the increase in tidal range and so on. This new high water level, the council says, would put the risk of flooding at about 1 in 10,000 in 1980, about 1 in 6,000 in 2010 and about 1 in 4,000 in 2030. At present, 55 square miles of London, with a population of 1,200,000 people, are below this new level. Walls an extra six feet high along the river banks would, however, be unacceptable from the amenity point of view in most parts of London. The council has therefore looked into other ways of 